\title{
Polskie reakcje na I rozszerzenie Wspólnot Europejskich o Wielką Brytanię, Danię, Irlandię (1961-1973)
}

Po podpisaniu traktatów rzymskich Europejska Wspólnota Gospodarcza wstapiła na ścieżkę intensywnego wzrostu gospodarczego, który swym zasięgiem objął wszystkie kraje ówczesnej „szóstki”. Swobodna wymiana towarów, usług, siły roboczej i kapitału w obrębie państw członkowskich doprowadziła do wzrostu prosperity jej społeczeństw. Rozwój gospodarczy państw Wspólnego Rynku budził podziw, ale zarazem obawę wśród innych państw starego kontynentu, gdyż od początku współpracy państw EWG wzrost ich produkcji przemysłowej następował szybciej niż np. w Wielkiej Brytanii i USA (w latach 1957-1960 produkcja przemysłowa w EWG wzrosła o 24\%, a w Wielkiej Brytanii o 15\%) (Lastawski, s. 172). W konsekwencji tego państwa kapitalistycznej Europy, zważywszy na pozytywne rezultaty integracji gospodarczej „,małej Europy” zaczęly rozważać przystąpienie do Wspólnego Rynku. Umożliwiał im to art. 237 traktatu rzymskiego o EWG: „Każde państwo europejskie może ubiegać się o przyjęcie do Wspólnoty" (Traktat w sprawie utworzenia Europejskiej Wspólnoty Gospodarczej, 1957, s. 1088).

Odwołując się do art. 237 traktatu rzymskiego o EWG, między lipcem a sierpniem 1961 roku trzy kraje zachodniej Europy złożyły formalne wnioski o członkostwo w EWG. Była to Wielka Brytania, Dania i Irlandia. Wśród kandydatur najwięcej kontrowersji wzbudzała Wielka Brytania, która już od okresu dwudziestolecia międzywojennego dystansowała się do propozycji integracyjnych na starym kontynencie, prezentując $w$ polityce zagranicznej wyrachowany pragmatyzm. W okresie powojennym, choć zapraszana przez Francję, nie była stroną planu Schumana i wielokrotnie dawała do zrozumienia krajom późniejszej „szóstki”, że Wielka Brytania nie jest małą wysepka, lecz centrum Commonwealthu. Brytyjczycy z powodów językowych, politycznych, gospodarczych, finansowych, instytucjonalnych czują się bardziej związani z mieszkańcami Australii, Nowej Zelandii, aniżeli z mieszkańcami Europy (Mikołajczyk, s. 93). Wobec kolejnych inicjatyw integracyjnych - powołanie EWG w 1957 roku - również pozostawała bierna, sądząc że: gigantyczny projekt nie dojdzie do skutku i załamie się z powodu słabości, niezdecydowania lub opozycji Francji - tak jak w 1954 roku załamał się projekt Europejskiej Wspólnoty Obronnej. Poza tym ,specjalne partnerstwo" Brytyjczyków z USA i krajami Commonwealthu pretendowały Londyn do roli mocarstwa wyższego rzędu niż kontynentalne mocarstwa zachodnioeuropejskie. (Szerzej: Krasuski, 2006, s. 201).

Wśród głównych powodów zmiany orientacji Albionu na proeuropejską w wymienionym okresie należy wymienić: kryzys polityczny i gospodarczy w państwie spowodowany konsekwencjami tzw. wojny sueskiej, zatarg z USA, słabnącą pozycję 
przetargową Wielkiej Brytanii szczególnie wobec Francji oraz wzrost realnej siły gospodarczej EWG. Do 1959 r. niechętna postawa Francji pod rządami generała Charlesa de Gaulle'a oraz niejednoznaczne stanowisko pozostałych państw członkowskich były na tyle silne, aby powstrzymać Brytyjczyków w ich staraniach. Po 1959 r. Brytyjczycy z coraz większym zainteresowaniem śledzili gospodarcze dokonania EWG i rosnącą przepaść w poziomie życia obywateli na wyspach i kontynencie. Sondowali możliwość zakotwiczenia się we Wspólnocie, ale na własnych warunkach. Powstałe w $1960 \mathrm{r}$. z inspiracji państw skandynawskich i Londynu konkurencyjne wobec EWG Europejskie Stowarzyszenie Wolnego Handlu (EFTA) miało na celu wzmocnienie pozycji przetargowej Brytyjczyków, którzy w zamian za korzystne warunki akcesji mogli w każdej chwili zrezygnować z uczestnictwa w EFTA. Z drugiej strony bliskie powiązania ekonomiczne z państwami Commonwealthu oraz ,specjalne relacje” ze Stanami Zjednoczonymi pozwalały powątpiewać nawet sympatykom Brytyjczyków w zachodnich stolicach, czy rzeczywiście pragną oni silnego i trwałego zakotwiczenia się na kontynencie w strukturach Wspólnego Rynku. Dlatego też z oporami ze strony „szóstki”, a szczególnie ze strony Francji rozpoczęły się rokowania mające na celu włączenie tego potężnego państwa do jednoczącej się Europy. Wraz z Wielką Brytanią w 1961 r. wnioski o akcesję do EWG złożyły Irlandia i Dania, a w 1962 roku Norwegia (Ibidem, s. 205).

Tymczasem, za „żelazną kurtyną” władza ludowa w Polsce za pośrednictwem organów prasowych (m.in. „Trybuny Ludu”, „Polityki”, Polskiej Agencji Prasowej, Zagranicznej Agencji Prasowej) z dużym zainteresowaniem śledziła procesy jednoczenia się kapitalistycznej Europy. Z niepokojem obserwowała rozwój gospodarczy państw członkowskich zdecydowanie przewyższający możliwości państw socjalistycznych i przestrzegała przed integracją polityczną państw „szóstki”. W miarę rozszerzenia zasięgu i zakresu integracji zachodnioeuropejskiej starano się dyskredytować jej osiągnięcia, gloryfikując zdobycze socjalizmu. Na łamach periodyków naukowych (,Sprawy Międzynarodowe”, „Przegląd Zachodni”) oraz czasopism (,Ideologia i Polityka”, „Nowe Drogi”) rządzący Polską uwypuklali sprzeczności występujące w łonie europejskich państw kapitalistycznych, które dotyczyły m.in. odmiennych interesów gospodarczych dwóch bloków występujących w obrębie Europy: EWG i EFTA (Sołdaczuk, 1961, s. 69), realizacji Wspólnej Polityki Rolnej państw EWG, w ramach której przede wszystkim zagadnienie subwencjonowania rolnictwa dzieliło państwa członkowskie (Walat, 1973, s. 12). Z perspektywy władzy ludowej istotna była również rywalizacja ekonomiczna bloków gospodarczych EWG-RWPG. Tę utożsamiano z ideologiczną walką pomiędzy blokiem wschodnim a burżuazyjnym Zachodem, który - zdaniem władz w Polsce - „uciskał masy pracujące” (Rakowski, 1967, s. 4).

W sprzeciwie Francji wobec akcesji Wielkiej Brytanii do EWG oraz rywalizacji pomiędzy EFTA a EWG upatrywano szansę na osłabienie kapitalistycznej Europy i zapowiadano kryzys wśród jej członków (Dobroczyński, 1962, s. 82). Był to dowód na to, że nie burżuazyjne organizacje ponadregionalne, takie jak EWG czy EFTA opierające działalność na wolnym handlu i konkurencji, ale współpraca i komplementarność w ramach RWPG były gwarancją stabilnego rozwoju społeczeństw.

Z kolei szybki wzrost gospodarczy RFN łączono z rosnącą siłą militarną zachodnich Niemiec, które zagrażały bezpieczeństwu Polski oraz państwom socjalistycznym 
z ZSRR na czele. Dlatego też z jednej strony akcentowano, że RFN odradza się gospodarczo we Wspólnotach i rośnie w siłę (Grabska, 1961a, s. 88-89), ale z drugiej strony starano się pomniejszyć sukcesy gospodarcze zachodnich Niemiec, sugerując przecenianie ich osiagnnięć i wskazywano na wzrost znaczenia międzynarodowego RWPG.

Rozwój Wspólnego Rynku „małej Europy” łączono także z celami politycznymi i ekonomicznymi USA, którym zależało na utworzeniu jakiejkolwiek - ekonomicznej czy politycznej siły będącej przeciwwagą dla ekspansji komunizmu w Europie. Integracja miała bowiem pełnić funkcję wojskowo-przemysłowego oraz politycznego zaplecza Paktu Atlantyckiego: „,wspólny Rynek został uznany przez USA za podstawową organizacje gospodarczą bloku atlantyckiego w Europie zachodniej, za gospodarcze ramię NATO. Rozwój procesu integracji europejskiej jest zbieżny z celami NATO. Wspólnota powinna być przede wszystkim integracją polityczną państw, a następnie gospodarczą" (Majcher, s. 80).

\section{Droga do negocjacji}

Po podpisaniu traktatów rzymskich oraz powołaniu EFTA w Polsce akcentowano sprzeczności i konflikty występujące w łonie państw kapitalistycznych wynikające $\mathrm{z}$ funkcjonowania w Europie zachodniej dwóch gospodarczych ugrupowań. Liderem EFTA była Wielka Brytania, natomiast w EWG o to miano konkurowała Francja wraz z RFN. W periodykach naukowych oraz na łamach pism publicystycznych sugerowano, że już od końca lat pięćdziesiątych polityka francuskiego prezydenta Ch. de Gaulle'a w Europie zawsze zmierzała $w$ kierunku odegrania czołowej roli przez $\mathrm{V}$ republikę $w$,,małej Europie" i tym samym zdystansowania Wielkiej Brytanii, która miała dążyć do odzyskania dawnej, przedwojennej mocarstwowości również poprzez przewodnictwo w EFTA.

Priorytetowym celem polityki zagranicznej francuskiego prezydenta było wypchnięcie sojusznika Wielkiej Brytanii - USA z Europy, aby uniknąć pogłębiającego się uzależnienia starego kontynentu od amerykańskich wpływów. Według Stanisława Zabiełły, znanego przedwojennego dyplomaty, po 1945 r. pracownika Polskiego Instytutu Spraw Międzynarodowych i publicysty miesięcznika „Sprawy Międzynarodowe”: „po odmowie amerykańsko-angielskiej włączenia Francji do klubu atomowego państw NATO, ta starała się zwiększyć autorytet Francji poprzez podjęcie idei europejskiej, ale nie $\mathrm{w}$ formie integracji, (zachodnioeuropejskie państwo federalne), ale kierowanej z Paryża konfederacji pozostawiającej poszczególnym członkom pełną suwerenność narodowa. W tym celu Ch. De Gaulle szukał zbliżenia z Niemcami Zachodnimi, co jednak doprowadziło do dopuszczenia RFN do współkierownictwa w konfederacji zachodniej" (Zabiełło, 1961, s. 78). Jak zauważa Zabiełło w tym okresie Francja zdecydowanie negatywnie odnosiła się do akcesji Wielkiej Brytanii do EWG. Zdaniem publicysty miesięcznika ostatecznie nie osiągnęła także celu, jakim było zdominowanie „małej Europy”, gdyż partnerzy ugrupowania odnieśli się negatywnie do ewentualnej hegemonii francuskiej. Według publicysty miesięcznika polityka francuskiego prezydenta wzmocniła jedynie Niemcy zachodnie.

W tym okresie znana ekonomistka Wirginia Grabska rozszerzenie Wspólnot Europejskich o Wielką Brytanię i kolejne kraje łączyła z zagrożeniem odbudowy impe- 
rializmu ze strony - jak wówczas pisano - $\mathrm{NRF}^{1}$. Na łamach periodyku „Sprawy Międzynarodowe" zauważyła, że oprócz przypisanych statutowo celów ekonomicznych Europejska Wspólnota Gospodarcza zmierzała do zrealizowania konkretnych celów politycznych. Autorka postawiła taką tezę na podstawie analizy aktualnej sytuacji polityczno-ekonomicznej RFN. Jej zdaniem, realizując wcześniejsze etapy integracji europejskiej, Niemcy zachodnie osiagnęły wysoki poziom rozwoju ekonomicznego i odpowiednio wysoką polityczną pozycję. Oceniła również, że utworzenie EWG miało być przeciwwagą dla polityki Wielkiej Brytanii i w konsekwencji miało doprowadzić do zacieśnienia sojuszu pomiędzy - jak wówczas pisano - RFN a Francją. Jak się później okazało EWG stała się mniej dogodnym dla RFN miejscem ekspansji ekonomicznej i politycznej. Zdaniem Grabskiej zakładana penetracja RFN na rynkach EFTA, gdzie jak do tej pory dominowali Brytyjczycy, byłaby jeszcze dalej posunięta niż w ramach EWG. Dlatego też Niemcy zachodnie zaczęły zabiegać o rozszerzenie EWG o Wielką Brytanię: „NRF jest jak najbardziej zainteresowana w utworzeniu takiego bloku, albowiem osiagnięta przez nią pozycja ekonomiczna w EWG pozwala jej na zachowanie dominacji również w organizacji o szerszym zasięgu" - pisała (Szerzej: Grabska, 1961b). Na koniec artykułu zaznaczyła, że w przypadku akcesji Wielkiej Brytanii do EWG, w przyszłości Niemcy zachodnie będą konkurować w tym ugrupowaniu z Wielką Brytanią.

Z kolei Zofia Ciechomska na łamach „Nowych Dróg” w 1961 roku wskazywała na odmienne interesy państw skupionych w ramach EWG i EFTA w kontekście coraz częściej dyskutowanego członkostwa Wielkiej Brytanii w EWG. Wymieniła szereg różnic występujących między państwami (członkami ugrupowania) i zasugerowała, że integracja powinna się rozpocząć od harmonizacji gospodarek państw członkowskich. Za najważniejszy dotychczasowy, negatywny skutek wprowadzenia wolnego rynku autorka uznała rozbicie krajów Europy zachodniej. Jak zauważyła, zasadnicze różnice w kwestiach handlowych pojawily się już na początku lat sześćdziesiątych wraz z inicjatywą Wielkiej Brytanii dotyczącą powołaniu EFTA spośród 7 krajów Organizacji Europejskiej Współpracy Gospodarczej (OEEC). Według Ciechomskiej ta inicjatywa była koncepcją różniącą się od propozycji państw szóstki przede wszystkim przez fakt, że faworyzowała przemysłowe interesy Wielkiej Brytanii, która z kolei: „nie dawała odpowiedniego ekwiwalentu w postaci możliwości zbytu towarów dla tych krajów zarówno na terenie Anglii, jak również Commonwealthu. Francuzi, a w ślad za nimi inne państwa EWG zarzucają OEEC brak wspólnej taryfy celnej" (Szerzej: Ciechomska, 1961).

W dalszej części artykułu autorka oceniła strategię Wielkiej Brytanii. Zauważyła, że Wyspiarze zawsze traktowali Europejskie Stowarzyszenie Wolnego Handlu jako instrument ułatwiający porozumienie z krajami EWG. Była i jest czołowym producentem przemysłowym w tym ugrupowaniu i głównym kontrahentem handlowym tzw. „małej Europy”. Zdaniem autorki układ o EFTA: „zaostrza sprzeczności między państwami EWG" (Ibidem). Inicjując układ o EFTA Wielka Brytania chciała przeciwstawić się politycznie tandemowi francusko-niemieckiemu w EWG lub dominacji RFN

1 W dalszej części artykułu autor używa skrótu RFN. 
w ugrupowaniu. Ciechomska uważała, że inicjatywa Wielkiej Brytanii zmierzała do stworzenia modus vivendi między „szóstką” a „siódemką”. Zasadnicze rozbieżności między państwami, w niedługiej przyszłości doprowadzić miały do impasu w relacjach między państwami kapitalistycznymi. W jej przekonaniu właśnie dlatego USA weszły do OEEC, aby nie dopuścić do rozbicia jedności zachodu. W dalszej części obszernego artykułu oceniła ona postawy poszczególnych państw EWG wobec rozszerzenia procesu integracji na inne kraje europejskie. Za najbardziej zainteresowane integracją uznała kraje Beneluksu. Zauważyła jednak, że Holandia ma więcej interesów z krajami OEEC niż Belgia i Luksemburg. $Z$ kolei zainteresowanie Włochów dalszym etapem rozwoju wspólnego rynku wiązała przede wszystkim z koniecznością zmniejszenia poziomu bezrobocia w tym kraju, który miał się dokonać poprzez: ,swobodną cyrkulację robotników na wspólnym rynku" (Ibidem, s. 98). Zagrożenie dla bezpieczeństwa pokoju w Europie wiązała z postawą Republiki Federalnej Niemiec, która zabiegała o nowe rynki eksportu dla swojej produkcji przemysłowej, również w terytoriach zamorskich. W jej przekonaniu zachodnie Niemcy zabiegały o rozszerzenie procesu integracji europejskiej, motywując swe zamiary głównie względami politycznymi, gdyż: „eksport niemiecki nie może zmieścić się nie tylko na wspólnym rynku, ale również w całej Europie" (Ibidem, s. 99). Autorka, francuskie zaangażowanie łączyła z obawą o napływ towarów przemysłowych z Anglii, który zagrozić miał produkcji krajowej Paryża.

Ciechomska zwróciła również uwagę, że na początku 1961 roku, w obliczu zapowiadanych negocjacji Wielkiej Brytanii z EWG skończyła się przyjaźń między Francją a Anglią, a pojawił się nowy alians między Francją a RFN. Jej zdaniem Konrad Adenauer sojusz z Francją traktował przejściowo po to, aby Niemcy uzyskały pozycję hegemona w Europie. Na koniec artykułu podkreśliła, że USA wspierały integrację europejską, wykorzystując ją instrumentalnie do swych celów politycznych i militarnych. W jej przekonaniu chodziło o stworzenie na terytorium państw kapitalistycznych ośrodka skierowanego przeciwko obozowi socjalistycznemu (Ibidem, s. 94). Oceniła, że głównym motywem powołania Wspólnego Rynku był kryzys sueski i problemy surowcowe. Dlatego też Wspólny Rynek miał być etapem do utworzenia wspólnoty politycznej, a następnie „Stanów Zjednoczonych Europy” na wzór USA (Ibidem).

Latem 1961 roku Wielka Brytania rozpoczęła formalny etap starań o członkostwo w EWG. 22 lipca 1961 roku rząd konserwatywnego premiera Harolda Macmillana złożył wniosek o członkostwo we Wspólnotach Europejskich. 31 lipca tego roku premier Wielkiej Brytanii przedstawił sprawozdanie na ten temat deputowanym w Izbie Gmin.

Aż do stycznia 1963 roku w publicystyce polskiej pojawiło się niewiele informacji na temat negocjacji w sprawie rozszerzenia EWG o Wielką Brytanię i kolejne kraje. Dyskusja rozgorzała dopiero na początku 1963 roku, kiedy na skutek veta Francji brytyjska aplikacja została odrzucona. Prasa polska była szczególnie zainteresowana negocjacjami Wielkiej Brytanii z EWG. Zdecydowanie mniej miejsca poświęcała podobnym zabiegom Danii i Irlandii.

W styczniu 1963 roku Polska Agencja Prasowa informowała o atmosferze przygnębienia wśród elit politycznych w Londynie związanej z utrzymującą się w państwach „szóstki” dezaprobatą dla członkostwa Wielkiej Brytanii we Wspólnotach Europejskich. Korespondent PAP Maksymilian Berezowski informował, że po półtorarocznych negocjacjach sytuacja zbliżyła się do punktu krytycznego. Istotę sporu ujął 
następująco: „Charles de Gaulle'a i Adenauer zgodziliby się na udział Anglii w EWG, gdyby zrezygnowała ona $z$ bliskich powiązań z USA i Commonwealthem. Brytyjczycy starają się jednak zachować jedno i drugie" (Berezowski, 1963, s. 2). W tym samym komunikacie Polska Agencja Prasowa informowała, że Londyn, ewentualną propozycję stowarzyszenia Anglii z EWG zdecydowanie odrzucił.

W ocenie Stefana Arskiego, publicysty tygodnika „Polityka”, wieloletniego redaktora naczelnego tygodnika „Swiat” brytyjskie starania o akcesję do EWG były: „najdonioślejszym gestem określającym zwrot w polityce zagranicznej Wielkiej Brytanii, gdyż gest ten oznacza zerwanie z tysiącletnią tradycją suwerenności brytyjskiej. Macmillan podjął się likwidacji Brytyjskiej Wspólnoty Narodów" - stwierdził (Arski, 1963, s. 8). Arski zauważył, że decyzja ta będzie miała brzemienne skutki dla życia politycznego Brytyjczyków, gdyż: „ich parlament zejdzie do poziomu rady parafialnej” (Ibidem). Publicysta tygodnika zaznaczył, że dla brytyjskiego społeczeństwa argumenty o ekonomicznych korzyściach z przystąpienia do EWG wydawały się mieć pierwszorzędne znaczenie. Nie oznaczało to jednak, że brytyjskie społeczeństwo nie przyjmowało politycznych i socjalnych argumentów na rzecz integracji z EWG. Zauważył także, że brytyjski premier będzie zobowiązany zapewnić społeczeństwo, że w dyskusjach ze Wspólnym Rynkiem interesy Wspólnoty Narodów zostaną utrzymane na tym samym poziomie jak dotychczas. Arski z ironią uznał, że będzie to niezwykle trudne, gdyż jak dotychczas udało się uzyskać jedno zapewnienie: ,że import konserw z mięsa kangurów nie będzie narażony na żadne trudności" (Ibidem). Działacz PZPR nie dawał Wielkiej Brytanii większych szans na akcesję do EWG. Jego zdaniem impas w negocjacjach najbardziej uosabiał głos Francji: „Jeśli przyjęlibyśmy Wielką Brytanię na naszych warunkach byłby to koniec Wspólnoty Brytyjskiej, a jeśli na jej warunkach byłby to koniec wspólnego rynku" (Ibidem).

14 stycznia 1963 roku francuski prezydent Ch. de Gaulle odrzucił wniosek Wielkiej Brytanii o przystapienie do EWG. Tego dnia o godzinie 15.00, w Pałacu Elizejskim odbyła się konferencja prasowa, w której oprócz prezydenta Francji uczestniczyli m.in., premier kraju Georges Pompidou oraz minister spraw zagranicznych Maurice Couve de Murville. Na łamach „Trybuny Ludu” pojawiło się sprawozdanie ze spotkania. W komunikacie zacytowano de Gaulle’a, który zauważył, że: „między sześcioma państwami wspólnego rynku istnieją podobieństwa geograficzne, kulturalne, i w dziedzinie rolnictwa. Między nimi a Anglią istnieją zasadnicze różnice. Pytanie polega więc na tym, czy Anglia gotowa jest zmieścić się w ramach wspólnych taryf kontynentalnych, zrezygnować z sytemu preferencji wobec krajów Commonwealthu, przestać żądać przywilejów dla jej rolnictwa i przestać ciągnąc za sobą do Wspólnego Rynku inne kraje ze strefy wolnego handlu" (PAP, 1963, s. 2). Francuski prezydent podkreślił, że na te pytania może odpowiedzieć tylko Anglia. Rozważył także ewentualne stowarzyszenie Albionu z EWG wobec braku akcesji. Na koniec konferencji prasowej oświadczył, że: „Europa (siedmiu państw z Anglia), jedenastu czy nawet osiemnastu nie będzie odpowiadać koncepcji wspólnego rynku, gdyż stanie się w końcu kolosalną wspólnotą azjatycką zależną od Stanów Zjednoczonych kontrolowaną przez nie. Przy czym tendencją USA będzie "Wchłonięcie wspólnoty»" (Ibidem).

W tym czasie głos państw „,szóstki” wobec akcesji Wyspiarzy do EWG nie był jednolity. W obliczu trudnych negocjacji akcesyjnych Wspólnoty z Wielką Brytanią pol- 
skie organy prasowe informowały o „gestej” atmosferze towarzyszącej przyjazdowi władz RFN do Paryża. W niedzielę, 20 stycznia 1963 roku do stolicy Francji przybyli: kanclerz Konrad Adenauer, minister spraw zagranicznych Gerhard Schröder oraz minister obrony Kai-Uwe Von Hassel z nadziejami nie tylko na podpisanie traktatu o współpracy politycznej, gospodarczej, militarnej, wojskowej ${ }^{2}$, ale również na zmianę twardego kursu Francji wobec rozszerzenia EWG o Wielką Brytanię. Prasa polska informowała, że nastroje byly pesymistyczne i sam traktat niemiecko-francuski zszedł na plan dalszy wobec nieustępliwego stanowiska francuskiego prezydenta, krytykowanego również przez państwa Beneluksu (PAP, „Trybuna Ludu” z 22 stycznia 1963).

Dzień później na łamach tego samego dziennika opublikowano wystąpienie premiera Anglii Harolda Macmilana w Liverpoolu. W odpowiedzi na nieustępliwe stanowisko Francji szef rządu brytyjskiego przyznał, że Anglia poznała gorycz porażki, jednak nie tracił nadziei na członkostwo Wielkiej Brytanii w EWG w przyszłości. Przyznał, że: „przy dobrej woli obu stron w przyszłości może dojść do akcesji Anglii do EWG. Dodal, że: poparcie ze strony innych państw europejskich oraz USA pozwoli osiągnąć konstruktywne rozwiązanie sprawy udziału Anglii we Wspólnym Rynku mimo sprzeciwów de Gaulle'a" (PAP z 23 stycznia 1963, s. 1). Dodał również, że z punktu widzenia Wielkiej Brytanii zjednoczona Europa powinna ściśle współpracować ze Stanami Zjednoczonymi w dziedzinie politycznej, ekonomicznej i wojskowej.

W tym samym okresie na łamach „Polityki” pojawiły się zagraniczne opinie na temat braku zgody EWG na przystapienie do tego ugrupowania Wielkiej Brytanii. Odwołano się m.in. do treści artykułów prasy zagranicznej, m.in. amerykańskiej („Chicago Sun The Times”), która - krytykowała „szóstkę" za zbyt twarde stanowisko negocjacyjne wobec perspektyw członkostwa Wielkiej Brytanii w EWG przez co wynik negocjacji był ciaggle niepewny (Wspólny rynek - egoistyczny klub bogaczy, 1963, s. 8). Na łamach tygodnika zwrócono też uwagę że działalność ugrupowania krytykował nawet nowo wybrany kanclerz RFN Ludwig Erhard a pierwsze, powojenne, sukcesy ugrupowania były przeceniane. Były one bowiem wynikiem powojennej koniunktury, a nie wyjątkowości działań państw Wspólnego Rynku. Na łamach „Polityki” sugerowano, że dla przyszłości EWG i odzyskania przez nią reputacji istotną kwestią pozostaje członkostwo Wielkiej Brytanii w EWG: „Jeśli Wielka Brytania zostanie przyjęta na bazie kompromisu sprzecznych interesów, będzie to dużym krokiem naprzód, pociagnie to bowiem za sobą raczej powstanie liberalnej/atlantyckiej wspólnoty handlowej niż zamknięcie się w protekcjonistycznym bloku kontynentalnym" (Ibidem). Zapowiadano tym samym rozłam w ugrupowaniu: ,jeśli Francja przeszkodzi temu, Wielka Brytania nie przebaczy. Co więcej przyjaciele Wielkiej Brytanii wśród szóstki - Holandia i Belgia będą wyzwalać się spod kontroli EWG i jedność «szóstki» będzie zachwiana" (Ibidem).

Z kolei w „Tygodniku Powszechnym” w stałej rubryce Obraz tygodnia zacytowano oświadczenie wicekanclerza zachodnich Niemiec Ludwiga Erharda, który zawetowa-

2 Przyjazd delegacji zachodnioniemieckiej do Paryża wiązał się z podpisaniem Traktatu Elizejskiego pomiędzy RFN a Francja. 
nie wniosku przez prezydenta Francji dla brytyjskiego członkostwa w EWG nazwał „pogrzebem europejskim”. Niepowodzenie kilkunastu miesięcy negocjacji pomiędzy Wielką Brytanią a EWG nazwano natomiast poważnym ciosem tak dla sprawy integracji europejskiej, jak i solidarności atlantyckiej. W tygodniku pisano również, że głównie za sprawą prezydenta Francji, którego ambicją było stworzenie z EWG trzeciej siły w świecie pomiędzy ZSRR a USA, między Paryżem a Waszyngtonem rozpoczęła się zimna wojna („Tygodnik Powszechny”, 1963, s. 2).

W tym okresie w prasie polskiej podkreślano, że podpisanie Traktatu Elizejskiego o współpracy pomiędzy Francją i RFN - choć odbyło się w atmosferze przyjaznej i uroczystej - nie zniwelowało różnic między obu państwami w kwestii przystąpienia Wielkiej Brytanii do EWG (PAP, 1963, s. 2). Na kilka lat sprawa akcesji Wielkiej Brytanii do Wspólnego Rynku została zamrożona.

\section{Drugi wniosek Wielkiej Brytanii o czlonkostwo w EWG}

Brak zgody ze strony „,szóstki” dla członkostwa Wielkiej Brytanii w EWG w 1963 r. nie zniechęcił Wyspiarzy do ponownych starań. W obliczu trudnej sytuacji gospodarczej oraz obaw o izolację polityczna, Londyn podjął kolejną próbę integracji ze Wspólnym Rynkiem.

Na początku maja 1967 roku, stały korespondent PAP w Londynie Jerzy Kowalewski informował na łamach „Trybuny Ludu”, że premier Wielkiej Brytanii Harold Wilson w oświadczeniu złożonym w Izbie Gmin zakomunikował, że Wielka Brytania ponownie będzie starać się o akcesję do Wspólnego Rynku. Rząd Wielkiej Brytanii miał zamiar jednocześnie wystapić z wnioskiem o przyjęcie do Europejskiej Wspólnoty Wegla i Stali oraz EURATOMU. W oświadczeniu złożonym w Izbie Niższej brytyjskiego parlamentu Wilson zadeklarował podpisanie Traktatu Rzymskiego: ,jeżeli wprowadzi się do niego konieczne poprawki oraz jeżeli znajdzie się zadowalające rozstrzygnięcie odnośnie punktów uważanych przez Wielką Brytanię za trudne" (Kowalewski,1967a, s. 1). Zdaniem Kowalewskiego życzeniem brytyjskiego premiera było jak najszybsze rozstrzygnięcie tzw. „dużych” zagadnień, które ostatnio były dyskutowane pomiędzy stroną brytyjską a sześcioma państwami wspólnoty i od których zależało zapewnienie istotnych interesów W. Brytanii i Brytyjskiej Wspólnoty Narodów. Do wielkich zagadnień publicysta zaliczył: przepływ kapitału i rolnictwo, a w szczególności: „wpływ polityki rolnej EWG na koszty utrzymania w Wielkiej Brytanii i na strukturę oraz możliwości rozwojowe rolnictwa brytyjskiego; konsekwencje tej polityki dla budżetu i bilansu płatniczego; i wreszcie wpływ jej na sytuację krajów Commonwealthu, a zwłaszcza Nowej Zelandii oraz krajów produkujących cukier" (Ibidem). Zdając sobie sprawę z tego, że wspólna polityka rolna jest integralną częścią polityki EWG, premier Wielkiej Brytanii oczekiwał wprowadzenia okresów przejściowych dla jego kraju. Zapewniał także o nieugiętym stanowisku i determinacji rządu brytyjskiego w postanowieniu o przystapieniu do EWG. Moment akcesji Wielkiej Brytanii do Wspólnot brytyjski premier nazwał historycznym, mającym olbrzymie konsekwencje dla kraju Europy i świata. Tego samego dnia dziennik informował, że Dania będzie prowadziła rokowania o przyjęcie do EWG razem z Wielką Brytanią. 
Dzień później, na łamach „Trybuny Ludu” odnotowano reakcje rządów EWG na wystapienie brytyjskiego premiera. PAP informowała, że zarówno we Włoszech, jak i NRF z życzliwością odnoszono się do deklaracji Anglii. Z kolei w Paryżu i Brukseli przyjęto postawę wyczekującą i stawiano otwarte pytania o granice ustępstw ze strony Londynu. Korespondent PAP w Londynie Jerzy Kowalewski przeanalizował z kolei reakcje brytyjskich parlamentarzystów wobec decyzji przystapienia do EWG. Zauważył, że 75 posłów Labour Party było przeciw decyzji rządu Wilsona i podpisało w związku z tym specjalny manifest. W dokumencie podkreślono m.in.: „Dla wielu ludzi EWG jest ekonomiczną podporą Paktu Północnoatlantyckiego [...] a widoki na utrzymanie więzi z Europa Wschodnią zostały w ten sposób zniweczone [...] w istocie rzeczy EWG zmierza do pogłębienia podziału Europy" (Kowalewski, 1967b, s. 2).

Jeszcze przed zaplanowaną na 4 maja 1967 roku w Izbie Gmin trzydniową debatą w sprawie członkostwa Wielkiej Brytanii w EWG, rząd brytyjski opublikował jedną z białych ksiag (dokumentów przyjętych przez rząd przed planowaną akcesją). Były w niej zawarte najbardziej kontrowersyjne dla gospodarki brytyjskiej zagadnienia związane z realizacją wspólnej polityki rolnej EWG, m.in. z podwyżkami cen żywności: masła, cukru, wołowiny. Na łamach artykułu: Wilson chce uniknqć veta Paryża podkreślono, że brytyjski premier był bardzo ostrożny w swoich wypowiedziach, aby nie narazić się najbardziej sceptycznemu wobec Wielkiej Brytanii krajowi - Francji (PAP, 1967a, s. 1).

Debata w Izbie Gmin zakończyła się zwycięstwem zwolenników Wspólnego Rynku i polityki premiera Wilsona. 488 posłów głosowało za, a 62 było przeciw akcesji. Uroczyste złożenie wniosku przez Wielką Brytanię poprzedzone zostało komunikatem wysłanym przez premierów Danii, Szwecji i Norwegii do Brukseli, w którym zadeklarowali chęć włączenia ich krajów do Wspólnego Rynku. Poinformowali również, że ich kraje nie uczynią tego jednocześnie.

11 maja 1967 roku ambasador Wielkiej Brytanii przy EWG James Marjoribanks złożył w imieniu rządu brytyjskiego na ręce przewodniczącego Rady Ministerialnej Wspólnego Rynku Renata Van Eslandsa oficjalny wniosek o przyjęcie Wielkiej Brytanii do EWG oraz Euratomu. Po póltorej godzinie wręczył podobny wniosek przewodniczącemu Rady Ministerialnej EWWiS Antoin'owi Wehenkelowi o przyjęcie do EWWiS. W odpowiedzi parlamenty 6 państw Wspólnego Rynku przyjęły jednomyślną uchwałę wyrażającą zadowolenie z deklaracji o akcesji Wielkiej Brytanii do EWG, Euratomu i EWWiS (PAP, 1967b, s. 1).

W tym czasie prasa polska szeroko komentowała te wydarzenia. Znany z rzetelnych analiz publicysta ekonomiczny Dariusz Fikus na łamach „Polityki” ocenił, że Harold Wilson podjął ponowną próbę akcesji Wielkiej Brytanii do EWG, ale czynił to ostrożniej niż jego poprzednik Harold Macmillan. Podróżował, sondował, dyskutował i badał opinie przedstawicieli państw członkowskich EWG. Jego zdaniem głównym motywem, którym kierowali się Brytyjczycy wiążąc swą przyszłość z EWG były (tak jak ostatnio) względy gospodarcze. Dlatego decyzja ta ucieszyła wielu przemysłowców i eksporterów brytyjskich oraz ponad 90\% brytyjskich koncernów. Dziennikarz „Polityki” zauważył, że decyzje premiera popiera 57\% społeczeństwa, gdyż większość społeczeństwa łączy wejście do EWG z odejściem od kosztownej polityki „na wschód od Suezu”. Jak zauważył: „wstąpienie do EWG ma być zastrzykiem dla przemysłu, 
który dzięki konkurencji ulegnie przekształceniu. Jego struktura stanie się bardziej nowoczesna [...] Rozszerzone więzi z krajami EWG zastapią w przyszłości związki z biednymi i zacofanymi partnerami Commonewalthu, którzy coraz bardziej stawali się kulą u nogi Wielkiej Brytanii" (Fikus, 1967, s. 9). Oceniając stan gospodarki angielskiej, publicysta tygodnika zasugerował, że obecnie „schorowana” Wielka Brytania niewiele może wnieść do WE oprócz chłonnego rynku. Cieniem na współpracy Albionu z ,szóstką" kładła się też niestabilna pozycja funta szterlinga. Dlatego też, w opinii publicysty tygodnika, Wielka Brytania startuje do EWG bardziej z pozycji petenta niż partnera. Co ciekawe autor zwrócił uwagę, że Brytyjczycy stojący w opozycji do decyzji premiera, niekiedy wywodzący się nawet z tej samej partii, sugerowali, że EWG uznawana jest za ekonomiczne odbicie NATO. Tą uwagę podzielał też Fikus. Jego zdaniem akcesja Wielkiej Brytanii przygotować miała dogodny grunt pod dominację amerykańską w Europie. Wielka Brytania w nowej konfiguracji politycznej miała się stać „koniem trojańskim”, z którego USA będą rządzily Europą.

W kolejnych tygodniach organy prasowe $w$ Polsce informowaly o postępach $w$ negocjacjach EWG-Wielka Brytania. 18 maja na łamach „Trybuny Ludu” zamieszczono notatkę z wypowiedzią Ch. De Gaulle'a na temat integracji Wielkiej Brytanii z EWG. Prezydent Francji koncyliacyjnie zapowiedział: „Nie ma mowy ani nigdy nie było mowy o francuskim veto wobec kandydatury brytyjskiej do Wspólnego Rynku. Problem polega tylko na tym, czy możliwe jest $\mathrm{w}$ tej chwili dojście do porozumienia na takich warunkach, by zachować dotychczasowe osiagnięcia wspólnego rynku. Dzisiejsza EWG jest rezultatem 10 lat prac i wysiłków i może przyjąc Wielką Brytanię tylko po daleko idących przekształceniach w tym kraju" (PAP, 1967c, s. 1). W dalszej części wypowiedzi przywódca Francji rozważał różne scenariusze i ostatecznie opowiedział się za wstrzymaniem akcesji Wielkiej Brytanii do EWG aż zmiany wewnętrzne i zewnętrzne, jakie przechodzi ten kraj zakończą się. Zapewnił jednak, że po tym czasie: „z ogromną radością przyjmie do kontynentalnej szóstki wspaniały zdolny i odważny naród angielski, który po głębokich przemianach politycznych, i ekonomicznych będzie już mógł do tej szóstki się dołączyć” (Ibidem). Na łamach „Polityki” oceniono gest De Gaulle'a za: „odmowę w rękawiczkach”. W odpowiedzi premier Wilson powiedział, że „nie - nie jest żadną odpowiedzią” („Polityka”, 1967a, s. 2).

10 czerwca na łamach „Polityki”, w stałej rubryce Kraje Kapitalistyczne pojawiła się informacja o konferencji państw EWG w sprawie przyjęcia Wielkiej Brytanii do Wspólnot Europejskich. W komunikacie poinformowano, że nie przyniosła ona żadnych konkretnych decyzji w sprawie przyjęcia do EWG Londynu. Poinformowano tylko o decyzji w sprawie fuzji EWG, Euratomu, EWWiS (Kraje kapitalistyczne, 1967b, s. 2).

Od początku października 1967 roku w grupie państw członkowskich EWG trwała dyskusja nad włączeniem Wielkiej Brytanii do Wspólnego Rynku.

Z kolei w Londynie, jeszcze przed głosowaniem ,państw szóstki” nad wnioskiem Wielkiej Brytanii o członkostwo w EWG trwały burzliwe dyskusje na temat akcesji $\mathrm{z}$ „małą Europą". Londyński korespondent PAP Jerzy Kowalewski informował, że 6 października 1967 roku większością 4147 tys. przeciwko 2032 tys. głosów Labour Paty zatwierdziła politykę rządu w sprawie włączenia Wielkiej Brytanii do Wspólnego Rynku. Zdaniem Kowalewskiego wszystko wskazywało na to, że wynik będzie ko- 
rzystny dla zwolenników integracji europejskiej, choć w londyńskim parlamencie deputowanych kontestujących kierunek polityki zagranicznej Wilsona nie brakowało. Ich argumenty dodatkowo mogły wzmocnić informacje prasowe docierające do Londynu z Brukseli, które były nieprzychylne dla rządu. Prasa londyńska informowała, że Komisja Wspólnego Rynku wprawdzie zaleciła krajom szóstki podjęcie rokowań z Wielką Brytanią, ale jej finanse i ekonomikę oceniła niezwykle krytycznie. W sprawozdaniu Komisja EWG stwierdziła: „ekonomikę brytyjską charakteryzuje fundamentalny brak równowagi, możliwe są nowe gwałtowne fluktuacje kursu funta, że bilans płatniczy znowu się pogarsza, że problem zadłużenia Wielkiej Brytanii przybiera na ostrości" (Kowalewski, 1967b). Ponadto Komisja EWG oceniła, że jeśli dojdzie do akcesji Wielkiej Brytanii do EWG, jej członkowie będą musieli mieć prawo do wypowiedzenia się co do podjęcia środków koniecznych dla polepszenia sytuacji Anglii (Ibidem). Do tzw. spraw trudnych Kowalewski zaliczył dewaluację funta, a więc - trudny wybór pomiędzy kursem europejskim w polityce zagranicznej a kursem waluty brytyjskiej. W obliczu tego korespondent PAP $\mathrm{w}$ Londynie zwrócił uwagę na przemówienie ministra spraw zagranicznych George'a Browna, w którym ten zaznaczył, że jeśli Wielka Brytania nie wejdzie w skład EWG pozostanie w izolacji, gdyż inne kraje EFTY uczynią to w niedługiej przyszłości. Ponadto, Brown stwierdził, że: „obecność Wielkiej Brytanii w EWG ma ułatwić dzieło odprężenia, polepszenia stosunków z Europą Wschodnią rozwiązać zagadnienia: Europy Środkowej i zagadnienie Niemiec" (Ibidem).

23 października 1967 r. w Luksemburgu spotkali się ministrowie spraw zagranicznych EWG, aby wypracować wspólne stanowisko. Prasa polska informowała, że zarówno minister spraw zagranicznych Włoch Amintore Fanfani oraz jego belgijski odpowiednik Pierre Harmel życzliwie odnieśli się do brytyjskiego wniosku. Natomiast szef resortu spraw zagranicznych Francji Maurice Couve de Murville podkreślił, że: „jego rząd nie przeciwstawia się samej zasadzie wejścia Wlk. Brytanii do EWG, ale położył nacisk na związane z tym trudności i odrzucił możliwość ustalenia jakichkolwiek konkretnych terminów"(PAP, 1967d, s. 2). Prasa polska informowała również o wizycie kanclerza zachodnich Niemiec Kurta Georga Kiesingera w Wielkiej Brytanii, który zapewnić miał o poparciu zachodnich Niemiec dla londyńskich starań (PAP, 1967e). W tym samym numerze, „Trybuny Ludu”, publicyści dziennika powołali się na agencję Reutera, która ujawniła treść rozmowy Ch. De Gaulle'a z ambasadorem Wielkiej Brytanii sir Patrickiem Reillym, która odbyła się 5 października. Wynikało z niej, że osiągnięcie jednolitego stanowiska w sprawie akcesji Wyspiarzy do EWG jest praktycznie niemożliwe. Podczas rozmowy prezydent Francji oświadczył, że Wielka Brytania będzie w stanie wejść do Wspólnego Rynku dopiero po 1972 roku (Ibidem).

O tym, że w dyskusji na temat członkostwa Wielkiej Brytanii w EWG najważniejszy głos ma Francja starał się przekonać Jerzy Kowalewski dzień później na łamach „Trybuny Ludu”. Przedstawił on francuskie warunki brytyjskiego członkostwa w EWG. Do najważniejszych zaliczył konieczność osiagnięcia równowagi bilansu płatniczego Wielkiej Brytanii i rezygnację z wiodącej roli funta traktowanej jako światowa waluta rezerwowa (Kowalewski, 1967c, s. 2). Publicysta przekonywał również, że premier Wielkiej Brytanii Harold Wilson był na tyle zdeterminowany w postanowieniu o konieczności członkostwa kraju w EWG, iż oświadczył, że Wielka Brytania nie zamierza przyjać negatywnej odpowiedzi na jej starania. Brytyjski korespondent za- 
uważył, że Londyn próbował ponownie zabiegać o poparcie RFN dla jej akcesji podczas wizyty bońskich władz w Londynie. Jednak w tym czasie zarówno minister spraw zagranicznych RFN Willy Brandt, jak i kanclerz Kurt Georg Kiesinger byli w deklaracjach bardziej powściaggliwi niż zwykle. W opinii korespondenta PAP w Bonn Artura Kowalskiego zarówno Kiesinger, jak i Brandt musieli zmieniać ton wypowiedzi po tym, co usłyszeli na konferencji w Luksemburgu. „Podobno Kiesinger, czytając tezy francuskiego ministra spraw zagranicznych wyglądał na Downing Street jak zmokły pudel" - dodał (Kowalski, 1967, s. 2).

W tym gorącym okresie prasa polska szczegółowo analizowała kolejny etap dyskusji nad członkostwem Wielkiej Brytanii w EWG. 27 października szef dyplomacji francuskiej Maurice Couve de Murville na posiedzeniu rządu francuskiego przedstawił sprawozdanie z sesji EWG. Jeszcze tego samego dnia stanowczo zaprzeczył jakoby Francja miała postawić veto przeciwko brytyjskiej akcesji, które doprowadziło do kryzysu w łonie szóstki (PAP, 1967f). Dzień wcześniej złożone w Bundestagu deklaracje kanclerza RFN oraz ministra spraw zagranicznych zachodnich Niemiec potwierdzily zaistniały impas w rozmowach z Wielką Brytanią. Choć obaj twierdzili, że nie dopuszczą do kryzysu w EWG i będą dbali zarówno o dobre kontakty z Paryżem (mającym najwięcej zastrzeżeń do akcesji Wielkiej Brytanii) oraz z Londynem, to jednak minister Brandt: ,trochę melancholijnie stwierdzil, że nie wiadomo wcale, kiedy zostaną podjęte rokowania w sprawie wejścia Anglii do EWG" (PAP, 1967g, s. 2).

Niejednoznaczna postawa państw szóstki nie zniechęcała Londynu do starań o akcesję. Tego samego dnia minister spraw zagranicznych Wielkiej Brytanii George Brown powiedział dyplomatycznie w parlamencie, że jest bardzo zadowolony, że może liczyć na poparcie RFN w negocjacjach. Zasugerował również, że fakt iż funt jest światową walutą rezerwową nie może być przeszkodą na drodze do zjednoczenia Wielkiej Brytanii ze Wspólnym Rynkiem (PAP, 1967h, s. 2).

Wobec nieustępliwego stanowiska państw „szóstki” - a szczególnie Francji wobec brytyjskiego członkostwa w EWG minister skarbu Wielkiej Brytanii James Callaghan opracował z bankierami londyńskiego centrum finansowego propozycję określenia roli i pozycji funta sterlinga po akcesji do EWG. Miało to zażegnać spory między "szóstką" a Wielką Brytanią. Callaghan uznał, że prezydent Francji niesłusznie negatywnie oceniał bilans płatniczy Wielkiej Brytanii. Zaznaczył też, że do najważniejszych zagadnień finansowych, które powinny być dyskutowane przez strony należały:

- obietnice obu stron: „szóstki”, jak i Wielkiej Brytanii, że nie będą miały miejsca ataki lub dążenia do osłabienia pozycji jakiejkolwiek waluty narodowej „małej Europy”;

- wyjaśnienie podstawowych faktów związanych z określeniem roli funta jako waluty rezerwowej i przede wszystkim przekonanie państw EWG, że strefa szterlingowa, nie istnieje tylko dzięki intencjom rządu brytyjskiego, ale dlatego że świat wybrał swego czasu właśnie funt szterling, jako walutę rezerwową:

- określenie czy poza Wielką Brytanią, którekolwiek państwo z EWG mogłoby pełnić podobną rolę jak Wielka Brytania $w$ finansowym świecie;

- zabezpieczenie interesów i praw obecnych posiadaczy funta szterlinga jako waluty rezerwowej (PAP, 1967j, s. 2).

W tym samym numerze „Trybuny Ludu” inny, stały korespondent PAP w Bonn - późniejszy dyrektor tej agencji Janusz Roszkowski pisał, że kanclerz RFN Kurt Georg 
Kiesinger był rozczarowany obstrukcyjnym stanowiskiem Francji i nie spodziewał się tak wielkiej determinacji Paryża w negowaniu możliwości członkostwa Wielkiej Brytanii w „,małej Europie”. Paryż bowiem nie określił nawet hipotetycznej daty przyjęcia Wielkiej Brytanii do EWG. Zdaniem Roszkowskiego niezłomnej postawie Francji wobec Wielkiej Brytanii towarzyszyła coraz silniejsza dezaprobata dla działań zachodnich Niemiec (PAP, 1967j, s. 2).

W tym czasie na łamach „Tygodnika Powszechnego" informowano, że Francja nakłania parterów z EWG do wysunięcia wstępnych żądań pod adresem Wielkiej Brytanii, że w obecnej sytuacji rozpoczęcie negocjacji na temat jej przystapienia do EWG jest niemożliwe (Obraz tygodnia, 1967a, s. 1).

30 października „Trybuna Ludu” powołując się na PAP zamieściła sensacyjną informację o możliwości zmiany kursu w polityce zagranicznej Wielkiej Brytanii na antywspólnotowy - wobec kolejnego już veta dla jej członkostwa w EWG. Powołując się na publikacje „Financial Times”, „Daily Mirror”, „Dailly Express” oraz „The Sun” Polska Agencja Prasowa zwróciła uwagę, że reorientacja polityki Londynu może doprowadzić do wycofania jej armii znad Renu i tym samym zminimalizowania zobowiązań wobec NATO. Wycofania się z porozumienia mocarstw w sprawie Berlina i zawarcia osobnego układu z ZSRR, a także odejścia od poparcia zjednoczenia Niemiec i tym samym uznania NRD (PAP, 1967k, s. 2).

Tygodnik „Polityka” potwierdzał te informacje, a jego publicyści dodawali, że ta sytuacja z pewnością ucieszy dużą część angielskiej opinii publicznej oraz dużą grupę posłów Izby Gmin. Takie informacje miał przedstawić lord Alun Chalfont - brytyjski negocjator z państwami członkami EWG na spotkaniu w Lozannie (Kraje kapitalistyczne, $1967 \mathrm{~d}, \mathrm{s.}$ ).

Natomiast Halina Różańska na łamach tygodnika „Ideologia i Polityka” przystapienie Wielkiej Brytanii do EWG interpretowała jako: „przezwyciężenie nacisku potężniejszego rywala i rozładowanie sprzeczności interesów gospodarczych narastających między EWG a EFTA" (Różańska, 1970).

12 listopada 1967 w stałej rubryce „Tygodnika Powszechnego” Obraz tygodnia poinformowano, że francuski przywódca Charles de Gaulle dopuszcza tylko możliwość stowarzyszenia Wielkiej Brytanii z EWG (Obraz tygodnia, 1967b, s. 1).

\section{Po akcesji}

Po śmierci prezydenta Charlesa de Gaulle'a w 1970 r. Francja dokonała reorientacji polityki wobec rozszerzenia Wspólnego Rynku o Wielką Brytanię i kolejne kraje. Nowy prezydent Georges Pompidou z pewnym niepokojem patrzył na RFN i dynamicznie rozwijającą się ,nową politykę wschodnią" koalicji SPD-FDP po wyborach do Bundestagu w 1969 r. Upatrywał w tym zagrożenia dla integracji europejskiej w wyniku nadmiernego zaangażowania się wschodniego sąsiada Francji w problemy bloku radzieckiego. Podobnego zdania był premier Edward Heath, który wraz z partią konserwatywną wygrał wybory parlamentarne w $1970 \mathrm{r}$. w Wielkiej Brytanii. Jako były oficer brytyjskich wojsk okupacyjnych w Niemczech, dobrze znający realia na kontynencie, $\mathrm{z}$ dużą determinacją parł do zakotwiczenia Zjednoczonego Królestwa w strukturach 
EWG. Wspólnie z Francją reaktywował znaną jeszcze z okresu I wojny światowej entente cordiale, a symbolami tej współpracy była budowa ponaddźwiękowego samolotu pasażerskiego Concorde i tunelu pod kanałem La Manche (Koszel, s. 37).

22 stycznia 1972 r. podpisano traktat o przystąpieniu do EWG z Danii, Norwegii, Wielkiej Brytanii i Irlandii. Jednak formalnymi członkami Wspólnoty od 1 stycznia 1973 roku stały się trzy państwa, bez Norwegii, której obywatele wypowiedzieli się w referendum przeciw członkostwu. Jak się wkrótce okazało, pierwsze lata akcesji dla nowych członków okazały się niezwykle trudne. Skutki kryzysu energetycznego oraz recesja gospodarcza dały się odczuć w Europie, a wspólna polityka rolna oraz nowe regulacje prawne i instytucjonalne EWG skutecznie osłabiały optymizm zwolenników państw członkowskich Wspólnego Rynku. W tym okresie na łamach prasy polskiej pojawiło się wiele interesujących komentarzy na temat rozszerzenia EWG i wynikających z tego konsekwencji.

Wojciech Bukowski na łamach „Polityki” zauważył, że po wstąpieniu Wielkiej Brytanii do EWG: ,zamknęła się ostatnia karta przeszło stuletniej polityki imperialnej, a otwarła się nowa karta polityki europejskiej" (Bukowski, 1973, s. 13). W artykule autor postawił otwarte pytanie: czy po wstapieniu do EWG Wielka Brytania zdominuje szóstkę czy szóstka będzie rządziła Wyspiarzami? Bukowski sceptycznie odniósł się do możliwości przyjęcia przez Wielką Brytanię wszystkich obowiązków państwa członkowskiego. W jego opinii Wyspiarze sprowadzą EWG do ugrupowania mającego silne powiązania pozaeuropejskie, szczególnie z USA: „Istota rzeczy tkwi w tym, jak wiele Londyn doleje brytyjskiej wody do zbyt intensywnego dlań wina integracyjnego kontynentalnej szóstki" (Ibidem) - dodał. Zaznaczył również, że blok dziewiątki po rozszerzeniu o Wielką Brytanię, Irlandię i Danię będzie nowym, istotnym podmiotem w polityce międzynarodowej. W jego opinii ta gospodarcza potęga będzie zwiększać obroty handlowe w kontaktach ze światem i jednocześnie realizować politykę dyskryminacyjną względem państw trzecich. Na łamach obszernego artykułu autor zwrócił uwagę, że głównym motywem akcesji Wielkiej Brytanii do Wspólnego Rynku było uzyskanie silnego bodźca dla jej gospodarki. Na koniec artykułu autor zaznaczył, że po rozszerzeniu EWG o Wielką Brytanię USA przewidują trudności w handlu artykułami rolnymi z EWG ze względu na twardy kurs polityki CAP. Dlatego też czekają na objęcie resortu spraw zagranicznych przez Brytyjczyka, który mógłby się stać obrońcą interesów amerykańskich we Wspólnym Rynku.

Z kolei Bogdan Kołodziejski - korespondent PAP w Kopenhadze - informował, że społeczeństwo duńskie przeżywa rozczarowane po wejściu do EWG. Nie zgadza się z regulacjami instytucjonalnymi i prawnymi Wspólnot oraz ze szczególnie trudną do przyjęcia wspólną polityką rolną EWG. Publicysta „Trybuny Ludu” zwrócił uwagę, że krótko po akcesji do EWG w rządzącej Danią - Socjaldemokratycznej Partii zawiązało się koło przeciwników integracji Danii ze Wspólnym Rynkiem. Ponadto ogłoszono powołanie Ludowego Ruchu Przeciwko Wspólnemu Rynkowi. Publicysta dziennika zaznaczył też, że wszyscy przeciwnicy Wspólnego Rynku akcentowali koszty, jakie ponosi obecnie gospodarka duńska, szczególnie w sferze rolnictwa, gdyż obszar ten po objęciu CAP nie może już być objęty dotacjami państwowymi. Jak stwierdził Kołodziejski: „trwają trudne rokowania nad przedłużeniem interwencji państwa w obronie cen produktów rolniczych... wzrost cen ziemi związany z perspektywą zalewu 
obcego - głównie zachodnioniemieckiego kapitału zagraża egzystencji najbiedniejszych małorolnych chłopów" (Kołodziejski, 1973, s. 2). Stwierdził, że koszty przystąpienia do Wspólnego Rynku są już widoczne, korzyści zaś pozostają mgławicą.

Dzień później na łamach „Trybuny Ludu” Władysław Krajewski, w artykule Wielka Brytania w EWG relacjonował, że rok 1973 - przystapienia Wyspiarzy do Wspólnego Rynku otwiera nową europejską kartę, nie mniej trudno określić jaka ona będzie. Według autora konserwatywny premier Edward Heath - byl euroentuzjastą który uważał, że: „członkostwo stworzy nowy wymiar możliwości i wpływów dla kraju, który po akcesji ma ambicję nie tylko grać pierwsze skrzypce w EWG, ale siegnąć po pałeczkę dyrygenta" (Krajewski, 1973a, s. 2) Korespondent dziennika w Londynie ocenił, że członkostwo Wielkiej Brytanii w EWG wiąże się z wielomilionowymi wpłatami do kasy wspólnot, które wyłożyć zobowiązała się Wielka Brytania. W artykule wymieniał kolejne negatywne skutki akcesji, których obawiało się społeczeństwo brytyjskie, a więc przede wszystkim wzrost cen produktów. Krajewski zwrócił uwagę na reakcje opozycyjnej wobec polityki premiera Labour Party, która głośno akcentowała zagrożenie dla brytyjskiej suwerenności po włączeniu do EWG: „przystapienie do EWG pociaga za sobą obowiązkowy import na wyspę kilku tysięcy postanowień obcych brytyjskim tradycjom" (Ibidem). Zdaniem Krajewskiego paradoks sytuacji Wielkiej Brytanii polegał na tym, że partia rządząca ma większość parlamentarną, pieczęć królewską na wniosku, ale nie ma społecznego poparcia dla członkostwa Wielkiej Brytanii w EWG.

4 stycznia 1973 roku na łamach „Trybuny Ludu” pojawił się artykuł Stanisława Albinowskiego zatytułowany Na etapie decyzji. W artykule autor zaznaczył, że po rozszerzeniu EWG o kolejne kraje zwiększył się potencjał ludnościowy i finansowy tzw. dziewiątki, ale nie daje on pełni obrazu wspólnoty. Zaznaczył, że przed państwami - członkami EWG stoją poważne problemy i wyzwania. Do najważniejszych autor zaliczyl: stworzenie unii walutowej, którą będzie trzeba budować opracowując politykę antyinflacyjną oraz stworzenie unii politycznej, której realizację przeniesiono na początek lat osiemdziesiątych. W opinii autora, aktualnie najbardziej niebezpieczną polityką wspólnotową realizowaną przez państwa dziewiątki była polityka handlowa, która dyskryminuje polityki handlowe innych krajów, również nie socjalistycznych. Albinowski zwrócił także uwagę na zmianę na fotelu przewodniczącego Komisji EWG (od 1973 roku stanowisko objął były minister finansów Francji w rządzie premiera Murville`a - Francois-Xavier Ortoli). Publicysta wyraził nadzieję, że ta postać może przyczynić się do pozytywnej zmiany kierunków współpracy EWG z państwami socjalistycznymi. Jednak dużo będzie zależało od relacji w trójkącie Paryż-Bonn-Londyn - dodał (Albinowski, 1973, s. 2).

5 stycznia 1973 roku na lamach „Życia Warszawy” pojawił się interesujący artykuł Władysława Krajewskiego - zatytułowany Londyńskie fanfary dla EWG. W artykule autor informował, że rząd brytyjski wydał 350 tys. funtów szterlingów na sfinansowanie uroczystości związanych z wejściem Wielkiej Brytanii do EWG. W inauguracyjnej przemowie premier brytyjskiego rządu Edward Heath wezwał naród do działań na rzecz europejskiej polityki zagranicznej, której realizacja pozwoli być poważnym partnerem dla Stanów Zjednoczonych i Japonii. Jak zauważył, nie wszystkim jednak to celebrowanie się podobało. Uroczystość zlekceważyli: były premier Wielkiej Brytanii 
Harold Wilson i większość członków partii labourzystowskiej. Autor zwrócił uwagę na słowa wypowiedziane przez ustępującego przewodniczącego Komisji EWG Sicco Mansholta. Podczas londyńskiego spotkania polityk holenderski zauważył, że: „w krajach EWG nie udało się generalnie poprawić warunków życia mas pracujących, a postępy integracji doprowadziły do poważnych napięć społecznych" (Krajewski, 1973b, s. 2).

W tym samym numerze dziennika Zygmunt Szymański zbadał oczekiwania krajów przystępujących do EWG: Wielkiej Brytanii, Irlandii, Danii. Podkreślił, że głównym argumentem przemawiającym za przystapieniem Albionu do „małej Europy” była chęć zdobycia większego terytorium do ekonomicznego działania oraz podniesienie poziomu życia mieszkańców Anglii. Autor podkreślił, że niewątpliwie zwiększono skalę produkcji we wspólnotach, a także zniesiono cła w wymianie handlowej między członkami ugrupowania. Jednak na poziom życia konsumentów niekorzystnie wpływała rozpiętość cen, które są nierównomierne i jest to poważne wyzwanie dla przyszłości integracji zachodnioeuropejskiej: „,najniższe ceny występują z reguly w Niemczech zachodnich, Holandii i Belgii, najwyższe we Francji, Włoszech" (Szymański, 1973, s. 3). Na koniec artykułu Szymański zauważył, że ,integracja zachodnioeuropejska osiągnęła jak dotąd ograniczone rozmiary, a Wspólny Rynek nie stał się jeszcze po prostu wspólnym rynkiem, na którego obszarze za ten sam towar płaci się, przynajmniej w zasadzie tę samą cenę" (Ibidem).

Na kolejne, negatywne konsekwencje rozszerzenia WE zwrócili uwagę publicyści „Trybuny Ludu”. W styczniowych numerach dziennika z 1973 roku informowali, że po akcesji Danii do EWG nastappił spadek cen na niektóre produkty, szczególnie alkoholowe w wyniku regulacji wspólnotowych. W obliczu zaistniałej sytuacji zauważyli, że granicę Danii masowo zaczęli przekraczać obywatele Szwecji, u których właśnie odnotowano wzrost cen alkoholu (PAP, 1973, s. 2).

Tego samego dnia na łamach dziennika pojawił się artykuł Johna Gollana - jednego z przywódców Brytyjskiej Partii Komunistycznej zatytułowany Sprzeczności imperializmu. Autor zwrócił uwagę na upadek imperialnej pozycji Wielkiej Brytanii po akcesji do EWG. Jego zdaniem przejawiała się ona w upłynnieniu kursu funta po to aby zakończyć funkcjonowanie strefy szterlingowej oraz w postawie Wielkiej Brytanii, która pierwsza naruszyła system sztywnych parytetów wprowadzając wahający się kurs funta szterlinga. Na koniec artykułu autor zaznaczył, że w obliczu rozszerzania EWG, rychłego upadku systemu z Bretton Woods sprzeczności w łonie państw kapitalistycznych są coraz bardziej widoczne (Gollan, 1973).

13 stycznia 1973 roku na łamach „Życia Warszawy” znawca spraw międzynarodowych, korespondent PAP w Bonn oraz Genewie Edward Dylawerski, rozważał scenariusze perspektyw rozwoju EWG poszerzonej od 1973 roku o trzy nowe kraje. Zaznaczył, że największe korzyści z członkostwa nowych krajów we wspólnocie osiągną Niemcy zachodnie: „wejście Wielkiej Brytanii do Wspólnoty nie zmieniło czołowej pozycji gospodarczej, jaką w EWG zajmuje NRF. Daje ona więcej niż 1/3 produktu społecznego całej dziewiątki. Na nią przypada też blisko 1/4 część obrotów handlowych we wszystkich dziewięciu państwach razem wziętych" (Dylawerski, 1973, s. 2). Zdaniem autora akcesja nowych członków, a szczególnie Wielkiej Brytanii do EWG stworzy doskonałą dla RFN sytuację do przeciwdziałania ewentualnej dominacji Francji w tym ugrupowaniu. Zdaniem Dylawerskiego, w aktualnej konfiguracji wspól- 
notę interesów będzie reprezentować duet: Bonn-Londyn, a rozszerzenie EWG o kolejnych członków ostatecznie prowadzić ma do utworzenia w świecie trzeciej siły pomiędzy ZSRR a USA.

W podobnym tonie wypowiedział się Kazimierz Dziewanowski na łamach tygodnika „Literatura”. Autor zastanawiał się czy bezsprzeczna siła finansowa i gospodarcza jednoczącej się Europy, pomimo braku jedności politycznej może decydować o statusie mocarstwowym Europy Zachodniej. Odniósł się do wypowiedzi prezydenta Francji Georgesa Pompidou i premiera Belgii Marka Eyskensa o utworzeniu do 1980 roku unii europejskiej i zaznaczył, że sprawa będzie dyskutowana w najbliższych latach 1974-1975. Zauważył także, że w Europie Zachodniej zaznaczyło się wyraźne zmęczenie ideą integracji europejskiej, szczególnie wśród młodzieży, a przyszły - deklarowany przez przywódców EWG - jednolity kształt wspólnoty jest niepewny. Nawiązał do wypowiedzi ustępującego ze stanowiska przewodniczącego Komisji EWG Sicco Mansholta, który stwierdził, że odległa dla Europejczyka zbiurokratyzowana EWG, w której stopa bezrobocia wzrasta, powinna: „przestać się interesować sprawami unii celnej, a przystapić w zamian do opracowania programu socjalnego obejmującego sprawę współuczestnictwa robotników w przemyśle, pomoc dla regionów zapóźnionych i sprawę wspólnej polityki rolnej, która by doprowadziła do obniżki cen żywności" (Dziewanowski, 1973, s. 2). Autor postawił otwarte pytanie: czy wspólnota państw kapitalistycznych jest w stanie zająć się sprawami socjalnymi? „brzmi to nieco utopijnie” - zaznaczył (Ibidem). Nawiązując do wypowiedzi holenderskiego polityka podkreślił, że ze względu na brak jedności politycznej i socjalnej pozycja EWG jest słaba. „Może się ona powiększyć tylko wtedy, gdy EWG przestanie być tylko wspólnotą wielkiego przemysłu i wielkiego kapitału, a stanie się wspólnotą ludzi pracy" - dodał (Ibidem).

Z kolei Ludwig Dembiński, wieloletni działacz katolicki na łamach ,Tygodnika Powszechnego" zwrócił uwage, że dzień 1 stycznia 1973 roku zakończył jeden rozdział integracji zachodnioeuropejskiej a rozpoczął drugi, który nazwał nawet nowym rozdziałem historii europejskiej. Podkreślił, że integracja Wielkiej Brytanii ze wspólnotami już od lat pięćdziesiątych była przedmiotem wielu kontrowersji, głównie z powodu wieloznacznego stosunku wyspiarzy do Europy. Jego zdaniem członkostwo Wielkiej Brytanii w EWG oznacza: „,definitywne odpisanie na straty zarówno imperializmu, jak i związanych nim ambicji mocarstwa światowego" (Dembiński, 1973, s. 2). Jak zauważył, z drugiej strony determinuje również głębokie przemiany w strukturze EWG oraz w polityce państw członkowskich. W opinii autora, sprzeczności interesów, kompromisy, antagonizmy w łonie szóstki nabiorą teraz nowej dynamiki, a solidarność członków ugrupowania i przyszłość EWG będzie wystawiona na próbę. W kontekście zapowiadanej na początek roku wizyty premiera Wielkiej Brytanii Edwarda Heatha w Waszyngtonie autor powątpiewał w lojalność Wyspiarzy wobec interesów Europy. Jego zdaniem Wielka Brytania po akcesji do EWG nie miała zamiaru zrezygnować z pozycji uprzywilejowanego sojusznika USA i będzie dalej myślała raczej kategoriami wspólnoty atlantyckiej niż europejskiej (Ibidem).

O niezwykle sceptycznym, aby nie powiedzieć niechętnym nastawieniu Brytyjczyków do członkostwa w EWG pisał Grzegorz Jaszuński na łamach „Życia Warszawy” w przededniu akcesji Albionu do tego ugrupowania. W artykule zatytułowanym: Anglia jako ubogi krewny autor przeanalizował gospodarczą sytuację Wielkiej Brytanii od 
końca XIX wieku do lat siedemdziesiatych XX wieku. W obszernym artykule zauważył, że od tamtego czasu Wielka Brytania przestała być mocarstwem i została przyjęta do EWG w charakterze ubogiego krewnego. Autor thumaczył zaistniałą sytuację obawami Brytyjczyków o wzrost cen i podniesienie stopy bezrobocia oraz koniecznością osłabienia więzi między Wielką Brytanią a Commonwealthem. Jaszuński przewidywał, że w ciaggu dwóch lat Brytyjczycy na własnej kieszeni odczują członkostwo w EWG. Dodał również, że „świadomość, że jest się tam ubogim krewnym, nie może im sprawiać przyjemności" (Jaszuński, 1973, s. 2).

O podobnym, negatywnym nastawieniu Duńczyków do Wspólnego Rynku pisał z kolei Tomasz Walat w artykule: Sznaps czy mleko? Autor wymienił liczne koszty ekonomiczne akcesji Danii do EWG i zaznaczył, że to co udało się uzyskać Duńczykom na obniżeniu cen na alkohole stracili na mleku i jego przetworach. Autor zauważył, że Duńczykom obiecywano, że po akcesji podwyższą cenę mleka i zwiększąjego eksport. Tymczasem już pierwsze posiedzenie ministrów rolnictwa EWG w poszerzonym składzie pokazało, że Dania pozbawiona subwencji z tytułu eksportu wieprzowiny do Wielkiej Brytanii dużo straci. Autor podkreślił, że społeczeństwo duńskie wini za tą sytuację m.in. niekompetentnego ministra rolnictwa Danii Iba Frederiksena, który nie znając języków obcych, podczas negocjacji nie wiedział co podpisuje. Na koniec artykułu zwrócił uwagę na masowe protesty społeczeństwa wobec podniesienia cen żywności podyktowane koniecznością wyrównania poziomu cen we wspólnocie. W kraju związki zawodowe zapowiedziały strajki z powodu zagrożenia dla młodego przemysłu duńskiego, który zobowiązany był po akcesji Danii zrezygnować z ceł ochronnych zabezpieczających rynek. Wśród innych przyczyn protestów duńskiego społeczeństwa autor wymienił: konieczność dostosowania Danii do podjętych przez Brukselę decyzji walutowych. W konkluzji autor skonstatował: ,przyszłość pokaże czy uda się Danii przynajmniej w części uzyskać te perspektywiczne korzyści, o jakich mówili zwolennicy EWG. Na razie jednak sadzonka duńska niedobrze przyjmuje się na «europejskim gruncie»" (Walat, 1973, s. 12).

W latach 1961-1973 władza w Polsce bacznie obserwowała rozwój procesu integracji europejskiej i rozszerzenia EWG o kolejne kraje, a w szczególności o Wielką Brytanię. Zdecydowanie mniej uwagi poświęcano staraniom dwóch innych państw: Danii i Irlandii. Na łamach periodyków naukowych oraz publicystyki w pierwszej kolejności akcentowano sprzeczne interesy i odmienne ambicje państw kapitalistycznych, gdyż ideę wolnego handlu propagowały zarówno państwa skupione we Wspólnym Rynku, jak również w ramach Europejskiego Stowarzyszenia Wolnego Handlu (Kuźba, 1970, s. 70). Rozszerzenie Wspólnot Europejskich o Wielką Brytanię łączono z ingerencją polityczną i ekonomiczną USA w interesy jednoczącej się Europy oraz przestrzegano, że sojusz ten determinuje postawę Wielkiej Brytanii do odegrania czołowej roli w EWG. W związku z powyższym obawiano się zarówno zwiększenia potencjału oraz siły gospodarczej i politycznej Wspólnego Rynku jak również aktywizacji polityki USA wymierzonej przeciwko państwom socjalistycznym, w tym przeciwko Polsce. Obawy te najlepiej ilustrują słowa Edwarda Możejki opublikowane na łamach „Polityki” na początku 1973 roku: „Teraz, bardziej niż kiedykolwiek nie jest dla nas obojętne jak wpłynie rozbudowa i dalszy rozwój EWG na tworzenie warunków współpracy. Musimy po prosu wiedzieć z czym mamy do czynienia" (Możejko, 1973, s. 11). 


\section{Bibliografia}

Albinowski T. (1973), Na etapie decyzji, „Trybuna Ludu” z 4 stycznia 1973 r.

Arski S. (1963), Commonwealth czy Common Market, „Polityka”, nr 4 z 26 stycznia 1963 r.

Berezowski W. (1963), Niewiara w powodzenie nowej rundy rokowań Anglii z EWG Gaulle'a, „Trybuna Ludu” z 16 stycznia 1963 r.

Bukowski W. (1973), Brytyjczycy w EWG, „Polityka”, nr 5.

Ciechomska Z. (1961), Wspólny Rynek Europy Zachodniej, „Nowe Drogi”, nr 1.

Dembiński L. (1973), EWG w nowym sktadzie, „Tygodnik Powszechny”, nr 4.

Dobroczyński M. (1962), Problemy integracji zachodnioeuropejskiej, „Sprawy Międzynarodowe”. nr 7.

Dylawerski E. (1973), O jakq Europę chodzi?, „Życie Warszawy”, nr 11 z 13 stycznia.

Dziewanowski K. (1973), Wspólnota niezbyt zjednoczona, „Literatura”, nr 3.

Fiskus D. (1967), Decyzja Wilsona, „Polityka”, nr 20 z 13 maja.

Gollan J. (1973), Sprzeczności imperializmu, „Trybuna Ludu” z 11 stycznia.

Grabska W. (1961a), Integracja gospodarcza jako czynnik odbudowy imperializmu zachodnioniemieckiego, „Sprawy Międzynarodowe”, nr 7.

Grabska W. (1961b), Ekspansja zachodnia NRF a problem integracji zachodnioeuropejskiej, „Sprawy Międzynarodowe", nr 9.

Jaszuński A. (1973), Anglia jako ubogi krewny, „Życie Warszawy”, nr 15 z 18 stycznia.

Kołodziejski B. (1973), Dania przed przystapieniem do EWG, „Trybuna Ludu” z 2 stycznia.

Koszel B. (1985), Antagonizmy i wspólpraca. RFN i jej zachodnioeuropejscy partnerzy 1969-1982, Poznań.

Kowalewski J. (1967), Wielka Brytania podejmuje nowa próbę wejścia do Wspólnego Rynku. „Trybuna Ludu" z 4 maja.

Kowalewski J. (1967a), Echa brytyjskiej decyzji przystapienia do EWG, „Trybuna Ludu” z 5 maja.

Kowalewski J. (1967b), Aprobata polityki wspólnorynkowej, „Trybuna Ludu” z 7 października.

Kowalewski J. (1967c), Rzq̨d Wielkiej Brytanii podtrzymuje starania wspólnorynkowe, „Trybuna Ludu" z 26 października.

Kowalski A. (1967), Bonn między Paryzem a Londynem, Deklaracja Kiesingera i Brandta w Bundestagu, „Trybuna Ludu” z 28 października.

Kraje kapitalistyczne (1967a), „Polityka” z 27 maja.

Kraje kapitalistyczne (1967b), „Polityka” z 10 czerwca.

Kraje Kapitalistyczne (1967c), „Polityka” z 4 listopada.

Kraje Kapitalistyczne (1967d), „Polityka” z 11. Listopada.

Krajewski W. (1973a), Wielka Brytania w EWG, „Trybuna Ludu” z 3 stycznia.

Krajewski W. (1973b), Londyńskie fanfary dla EWG, „Życie Warszawy” z 5 stycznia.

Krasuski J. (2003), Historia polityczna Europy Zachodniej 1945-2002, Poznań.

Kuźba A. (1970), Jak przebiegaja procesy integracji w Europie Zachodniej, „Ideologia i Polityka”, , nr 6.

Lastawski K. (2004), Od idei do integracji europejskiej, Warszawa.

Majcher J. (1962), Integracja Europy zachodniej, „Sprawy Międzynarodowe”, nr 5.

Mikołajczyk M. (2015), Wielka Brytania wobec integracji europejskiej w latach 1945-1950, „Przegląd Zachodni", nr 2. 
Możejko E. (1973), Piraci w EWG?, „Polityka”, nr 8 z 24 lutego.

Obraz tygodnia (1963), „Tygodnik Powszechny” z 10 lutego.

Obraz tygodnia (1967a), „Tygodnik Powszechny” z 29 października.

Obraz tygodnia (1967b), „Tygodnik Powszechny” z 12 listopada.

PAP (1963), Adenauer $i$ de Gaulle podpisali traktat o wspólpracy Francja-RFN, „Trybuna Ludu” z 24 stycznia.

PAP (1963), Adenauer przybyl do Paryża, "Trybuna Ludu” z 22 stycznia.

PAP (1963), Konferencja prasowa de Gaulle'a, „Trybuna Ludu” z 16 stycznia.

PAP (1963), Macmilan o impasie brukselskim, "Trybuna Ludu” z 23 stycznia.

PAP (1967a), Wilson chce uniknąc veta Paryża, „Trybuna Ludu” z 6 maja.

PAP (1967b), Wielka Brytania oficjalnie zgtosita akces do EWG, „Trybuna Ludu” z 12 maja.

PAP (1967c), Konferencja prasowa de Gaulle'a, „Trybuna Ludu” z 18 maja.

PAP (1967d), Batalia w Luksemburgu w sprawie kandydatury brytyjskiej do EWG, Francja znów przeciw, „Trybuna Ludu”, 25 października.

PAP (1967e), Londyn uzyska poparcie BONN w sprawie przyjeccia do EWG?, „Trybuna Ludu”.

PAP (1967f), Sprawozdanie z sesji EWG na posiedzeniu rzqdu francuskiego, „Trybuna Ludu” z 27 października.

PAP (1967g), Bonn między Paryżem a Londynem, Deklaracja Kiesingera i Brandta w Bundestagu. „Trybuna Ludu”, 28 października.

PAP (1967h), Brown za rokowaniami w sprawie przystapienia W. Brytanii do EWG, „Trybuna Ludu”, 28 października.

PAP (1967i), Propozycje Callaghana w sprawie roli funta szterlinga, „Trybuna Ludu” z 29 października.

PAP (1967j), Modyfikacja polityki bońskiej wobec Francji, „Trybuna Ludu” z 29 października.

PAP (1967k), Pogloski o zmianie polityki rzqdu Wilsona w wypadku nie przyjęcia Wielkiej Brytanii do $E W G$, „Trybuna Ludu” z 30 października.

PAP (1973), Inwazja Szwedów na Danię, „Trybuna Ludu” z 11 stycznia.

Rakowski M. (1967), Zorganizowana ideologia, „Polityka”, nr 4 z 28 stycznia.

Różańska H. (1970), Wewnętrzne sprzeczności a procesy integracyjne w obozie kapitalistycznym. „Ideologia i Polityka”, nr 6.

Sołdaczuk J. (1961), Niektóre aspekty ogólnego kryzysu kapitalizmu, „Nowe Drogi”, nr 4.

Szymański Z. (1973), Wspólny Rynek czy wspólny rynek, „Życie Warszawy”, nr 4 z 5 stycznia.

Traktat w sprawie utworzenia Europejskiej Wspólnoty Gospodarczej (1957), „Zbiór Dokumentów”. nr 5.

Walat T. (1973), Sznaps czy mleko?, „Polityka”, nr 14.

Wspólny Rynek - egoistyczny klub bogaczy (1963), „Polityka” z 19 stycznia.

Zabiello S. (1961), Francuska siła uderzeniowa, „Sprawy Międzynarodowe”, nr 3.

\section{Streszczenie}

Zasadniczym celem artykułu jest zbadanie reakcji władz Polskiej Rzeczpospolitej Ludowej wobec rozszerzenia zasięgu i zakresu integracji europejskiej w latach 1961-1973. W tym okresie wnioski o ezłonkostwo w EWG złożyły: Wielka Brytania, Irlandia i Dania. Analizę przepro- 
wadzono w oparciu o doniesienia prasowe Polskiej Agencji Prasowej, a także informacje opublikowane na łamach gazet i tygodników (,Trybuna Ludu”, „Polityka”), czasopism (,Nowe drogi”, „Ideologia i Polityka”) oraz periodyków naukowych („Przegląd Międzynarodowy”, „Przegląd Zachodni”).

Slowa kluczowe: Wielka Brytania, EWG, władza ludowa, akcesja, prasa polska, integracja europejska, Wspólny Rynek

\title{
The Polish response to the first enlargement of the European Community to include Great Britain, Denmark and Ireland (1961-1973)
}

\begin{abstract}
Summary
The primary objective of this paper is to examine the response of the authorities of the Polish People's Republic to the extending scope and range of European integration in 1961-1973. The following countries applied for EEC membership in this period: the United Kingdom, Ireland and Denmark. The analysis is conducted on the basis of press releases of the Polish Press Agency (PAP) as well as features published in newspapers and magazines ("Trybuna Ludu", "Polityka", "Nowe drogi", "Ideologia i Polityka"), as well as academic periodicals ("Przegląd Międzynarodowy", "Przegląd Zachodni").
\end{abstract}

Key words: Great Britain, European Economic Community, Communist authorities, accession, Polish press, European integration, Common Market 
